\title{
THE DICHOTOMY BETWEEN SIGNAL AND CONTENT AS BASIS OF BROADCAST COPYRIGHT: A KENYAN AND SOUTH AFRICAN PERSPECTIVE
}

\author{
Hezekiel Oira \\ LLB LLM \\ Dean, Mount Kenya School of Law \\ LLD Candidate, University of Zululand \\ Lonias Ndlovu \\ LLB LLM LLD \\ Associate Professor, Department of \\ Mercantile Law, School of Law \\ University of Venda
}

\section{SUMMARY}

The concept of broadcast copyright is one of the most controversial and nonfelicitous subjects, both at national and transnational levels. Most municipal copyright laws and relevant international instruments merely provide that broadcasting organizations shall enjoy protection over their broadcasts and programme-carrying signals. Some of those international instruments include The Rome Convention for the Protection of Performers, Producers of Phonograms and Broadcasting Organizations of 1961 (hereinafter "the Rome Convention"). Article 13 thereof grants specific exclusive rights against certain activities in relation to the broadcasts of broadcasting organizations. Additionally, Article 1 of the Rome Convention guarantees that its exercise and implementation shall leave intact and in no way affect the protection of copyright in literary and artistic works. The Agreement on Trade-Related Aspects of Intellectual Property Rights (hereinafter "the TRIPs Agreement") of 1994 follows the model of the Rome Convention, and under Article 14 (3) grants broadcasting organizations the same neighbouring rights as the latter does. In both instruments, the object of protection in a broadcast or broadcasts was never defined. The Convention Relating to the Distribution of Programme-Carrying Signals Transmitted by Satellite (hereinafter "the Satellite Convention") of 1974 does not grant broadcasting organizations any specific right but obliges Contracting Parties to prevent unauthorized distribution on or from their territories of any programme-carrying signal by any distributor for whom the signal emitted to or passing through the satellite is not intended. The protection conferred upon the broadcasting organizations under the above international instruments are replicated in the copyright laws of Kenya and South Africa without clarifying upon the property and the scope of protection of a broadcast. The failure to specifically define the subject matter of protection in broadcast copyright as well as its outer boundaries 
forms the genesis of the current controversy. Amid this controversy, this article examines two emerging global approaches around which broadcast copyright revolves, namely the content or rights-based approach, and the signal-based approach. Drawing from the two approaches, the article examines the extent to which they apply to Kenya and South Africa.

\section{$1 \quad$ INTRODUCTION}

The protection of copyright at the international and national levels is dogged with profound controversy. ${ }^{1}$ The controversy revolves around the subject matter of copyright protection in a broadcast. There are two integral elements around which the controversy spins, viz, the content and the signal. $^{2}$ There are two schools of thought in this discourse. The first one is anchored upon the protection granted to broadcasting organizations under the Satellite Convention. ${ }^{3}$ The protection under the Satellite Convention is based on the signal and thus the signal should form the substratum of broadcast copyright. Signal-based protection would leave intact and shall in no way affect the protection of copyright in the content embodied in the signal. Additionally, if protection is extended to content, works in public domain would come within the scope of protection once broadcast, and besides any extension of protection to content, it would create an overlapping of rights that would hurt consumers. The second school of thought posits that a signal is imperceptible and evanescent and therefore cannot form the basis of broadcast copyright protection. It further posits that copyright cannot subsist in an action of transmission but instead in the perceptible substance of broadcasts-the visual images or sounds that are encoded in signals by the broadcaster, transmitted and finally received by the public. The visual images or sounds constitute the underlying content of a broadcast.

Among the proponents of the content-based broadcast copyright are Colantuoni and Navazio. ${ }^{4}$ The duo argues that in sports broadcasts, events

1 The current World Intellectual Property Organization (WIPO) deliberations on the possible new international norm on the protection of broadcasting organizations started in April 1997 in Manila, Philippines with one of the authors of this article in participation as a delegate of the African Union of broadcasters. To date, no consensus has been generated on the specific object and scope of protection of broadcasters. From the proceedings of the conference, WIPO published a book that forms the point of reference over the ongoing deliberations. See WIPO WIPO Symposium on Broadcasting, New Communication Technologies and Intellectual Property (1998) 14.

2 This paper adopts the meaning of the term signal under Article 1 of the Satellite Convention, which defines a signal as an electronically generated carrier capable of transporting programs. The same article also defines a programme as a body of live or recorded materials consisting images, sounds or both embedded in signals, which the paper assimilates into the notion of content. The programme may, if created by the broadcasting organization and copyrightable, be independently protected as such and the protection is different from that broadcasters enjoy as neighbouring right holders; or the content may be acquired from third parties.

3 Each Contracting State undertakes to take adequate measures to prevent the distribution on or from its territory of any programme-carrying signal by a distributor for whom the signal emitted to or passing through the satellite is not intended. Article 2 Satellite Convention.

4 Colantuoni and Navazio “Intellectual Property Rights in Basketball” 2011 1-2 Int'l Sports LJ 61. 
themselves enjoy copyright protection at the stage of sports performance. ${ }^{5}$ This protection is designed to achieve a commercial function in order to stimulate long-term strategic investment in the industry. The sports performances upon transmission form part of the content and the duo are understood to be advocating a content-based neighbouring rights protection of a live telecast of sporting events. However, it should be noted that on the site, purposive sports events do not enjoy copyright. ${ }^{6}$ It is also generally accepted that purposive sports personalities are not performers because they do not perform any work. ${ }^{7}$ However, the Rome Convention gives member states latitude, by their laws or regulations, to extend the scope of its protection to artists who do not perform literary or artistic works. ${ }^{8}$ Colantuoni and Navazio's conceptualization of sports performance should be viewed in a broad and generic sense. Besides, a broadcast copyright, which is a form of neighbouring right, always exists irrespective of whether the underlying content is a work or not. ${ }^{9}$ Noting that the USA does not grant neighbouring rights to broadcasts is instructive and yet sports broadcasts are protected as cinematographic works. ${ }^{10}$ In Kenya and South Africa, the concept of audio-visual works or cinematograph film is defined so broadly as to include a recorded sports event and any other content. ${ }^{11}$ At any rate, the

5 Colantuoni and Navazio in Nafziger and Ross (eds) Handbook on International Sports Law (2011) 411. The duo make a general proposition for copyright extension to broadcasts of sports competition in order to reward the broadcasters' entrepreneurial efforts.

6 It is assumed that the movements and exploits of athletes are only aimed at the achievement of specific sporting results. It also argued that the movement of such athletes is so random and unpredictable and hence there is no room for creativity. See Kowalski The Rights to TV Broadcasts of Sports Events (unpublished LLM Thesis, Lapland University 2015) 25; Australia Olympic Committee v Big Fights Inc (1999) 46 IPR 53 par 23; Sports Claimants v Copyright Board (1991) 36 CPR 3D 483 par 16.

7 WIPO WIPO Neighbouring Rights Guide to the Rome Convention and to the Phonograms Convention (1999) 21. This view is based on the definition of performers in Article 3 of the Rome Convention to the effect that "performers means actors, singers, musicians, dancers, and other persons who act, sing, deliver, declaim, play in, or otherwise perform literary or artistic".

8 See Article 9. It is worthwhile to note that Kenyan and South African copyright laws grant protection to performances that are based on pre-existing works. However, some jurisdictions have extended protection to performances otherwise not based on pre-existing works like aesthetic sports and folklore-based activities.

9 Tran The Protection of Broadcasters' Rights in a Changing Technological Landscape: A View from South Korea (unpublished Master of Law in IP, WIPO Academy University of Turin 2016-2017) 10 par 2. When copyright subsists in the broadcast content, such content enjoys a two-tier protection. One is under the copyright that is granted to the owners, and the other is under neighbouring rights of the broadcaster over the broadcasts that embody such content. Conversely, if the content is not a work protected under copyright, the broadcaster will still enjoy neighbouring right for the protection is grounded upon the entrepreneurial efforts and not authorial activity.

10 The Court of Appeal of the USA held that sports events are not authored in the common sense of the word but copyright protection only extends to recorded broadcasts of live events. National Basketball Association and NBA Properties Inc v Motorola Inc Sports Sportstra (1997) US 2d Circuit 105F 3d 841 par 67; see also Nimmer and Nimmer, Nimmer on Copyright (2010) par 2:166.

11 See South African Copyright Act No 98 of 1978 s 1(1). It defines a cinematograph film as any fixation or storage by any means whatsoever on film or any other material of data, signal or sequence of images capable, when used in conjunction with any other mechanical, electronic device, of being seen as a moving picture and any reproduction, and includes the sounds embodied in a sound-track associated with the film, but shall not include a computer program; Copyright Act of Kenya Chapter 130 of 2001 s 2(1) defines an audio-visual works as any fixation in a physical medium of images, either synchronized with or without sound, 
copyright protection of broadcast is not dependent on the copyrightability or otherwise of the underlying content; a broadcast is a work independent of the underlying content. ${ }^{1}$

According to Sharma, copyright protection of a sport telecast should be based on the underlying content not only because of the entrepreneurial efforts of broadcasting organizations but also owing to their contribution to the diffusion of information and culture. ${ }^{13}$ Citing the USA as an example, Sharma points out that in the wake of the 1976 copyright law, recorded sports broadcasts are protected as cinematographic works.

On the other hand, Rafiei argues that a signal is an intangible and imperceptible property and therefore the use of a programme, something perceptible, as a basis of protection is common a practice. ${ }^{15}$ Rafiei further argues that the basis of broadcast copyright is the transformation and conversion of content into electronic pulses in form of broadcast signals or programme-carrying signals, which are then transmitted to the public. ${ }^{16}$ The public cannot receive and perceive the underlying content of a broadcast unless it is converted into a broadcast signal or programme-carrying signal, which is then transmitted. Rafiei's argument implies that protecting an empty signal is not economically viable and thus it must be embedded with content to make economic sense. The concept of a broadcast signal was amplified at various WIPO meetings; that a broadcast is an expression of the total programme output for which a broadcaster is legally, financially, and editorially responsible; it includes the securing of the necessary investment, expending skill, labour and technical resources needed to have the broadcast signal and its embedded content put together and delivered to the public.

In support of the content-based protection of broadcasts, the Australian High Court underscored the importance of content in determining substantiality of a broadcast in TCN Channel Nine Pty Ltd $v$ Network Ten

from which a moving picture may by any means be reproduced and includes videotapes and videogames but does not include a broadcast.

12 Tran The Protection of Broadcasters' Rights in a Changing Technological Landscape: A View from South Korea 10 par 2; see also Rome Convention Article 3(f) the definition of broadcasting revolves around the transmission by wireless means for public reception of sounds or images and sounds. It does not say that the images and sounds or sound must be those of a work.

13 Sharma Copyright Protection over Sports Broadcasts: A Global Perspective Paper presented at the $60^{\text {th }}$ ABU Sports Group Conference, Hong Kong (May 2017) 5.

14 See Sharma Copyright Protection over Sports Broadcasts: A Global Perspective 5; see also s 102(a)(6) 17 USA Copyright Act.

15 Rafiei The Possibility of Granting New Legal Protection and IP Rights to Broadcasting Organizations Against the Unauthorized Exploitation of their Broadcasts (unpublished PhD Thesis, University of Neuchatel 2015) 92.

16 Rafiei The Possibility of Granting New Legal Protection and IP Rights to Broadcasting Organizations Against the Unauthorized Exploitation of their Broadcasts 92. According to Rafiei, broadcasters are always the owners of their broadcast signals irrespective of the ownership of the content, and irrespective of whether the content is copyright protected or not.

17 See South Africa and Mexico Joint Reaction to Comments on the Draft Treaty WIPO Treaty on Broadcasting Organizations paper presented to the WIPO SCCR meeting on the Rights of Broadcasting Organizations, Geneva (15 May 2012) 2. 
Pty. ${ }^{18}$ In this case, the High Court placed reliance upon the visual images taken from the broadcasts in order to determine the substantiality of the work infringed. The fact that the concept of substantiality in copyright was pegged on the broadcast images implies that content is central to broadcast copyright. $^{19}$ In other words, perceptible elements would measure substantiality in a broadcast and not by a signal that is intangible. Thus, copyright in a broadcast subsists in the content of the broadcast and not in the imperceptible means of communication. ${ }^{20}$ This view receives support in Kenyon, who posits that the protection of broadcasts should be given to that which has the attributes of commercial significance for the broadcasters, identified by the use of the term a "broadcast" in the sense of a programme, in the same way, the words, figures, and symbols constitute a literary work. ${ }^{21}$

On his part, Handler contends that electromagnetic signals that are transmitted in a broadcast are evanescent, transient and imperceptible and any rights over those signals alone are ineffectual. ${ }^{22}$ The rights would be ineffectual because a signal falls outside the purview of the author's intellectual creation. It is further argued that broadcast signals per se cannot be protected under copyright or neighbouring rights ${ }^{23}$ because they are technical in nature and that there are other signal generating enterprises in the field of telecommunications that may also claim similar protection. Broadcast copyright based on content conforms with the existing technical, structural and functional characteristics and realities of the industry, having regard to the fact that a signal, in itself, has no commercial value separate from the programme it carries. ${ }^{24}$

Among the proponents of the signal-based protection, include Ricket and Creswell, who posit that the basis of broadcast copyright is the signal. The duo maintains, "[a]though it is possible that a broadcaster has applied considerable skill and judgment in the selection of and compilation of the broadcast, it does not seem those elements are part of Part $\mathrm{IV}^{25}$ protection.

18 (2001) 108 FCR 235 (in brevity the suit was that between 1999 and 2000, Network Ten Pty (Ten) rebroadcast on its weekly programme "The Panel" excerpts from twenty programmes originally broadcast by the rival network, TCN Channel Nine Pty Ltd (Nine). Consequently, Nine filed a copyright infringement suit against Ten based on unauthorized rebroadcasting. The issue before the Court was whether the broadcasts rebroadcast were substantial enough to meet the threshold of infringement).

19 TCN Channel Nine Pty Ltd v Network Ten Pty supra 36.

20 Laddie, Prescott, Victoria, Speck, and Lane The Modern Law of Copyright and Designs 3ed (2000) par 8:15

21 Kenyon (ed) TV Futures: Digital TV Policy in Australia (2007) 3. In Kenyon's view, a broadcast signal is legal metaphor for the ensemble of the broadcast output for which a broadcaster is responsible.

22 Handler "Panel Case and Television Broadcasts" 200325 Sydney LR 407.

23 Neighbouring rights, also referred to as related rights refer to the rights of performers and owners of recording companies as well as broadcasting organization, specifically refer to the right to publicly perform a performance, or sound-recording or broadcast. For an overview of the conceptual and international regime applicable to neighbouring rights, see generally Al-Balushi "Arab States start acceding to Arab Copyright and Neighbouring Rights Treaty" 2016 Journal of Intellectual Property Law and Practice 578-579.

24 Love Works in the Public Domain Become Copyrightable paper presented at the WIPO SCCR meeting on the Protection of Broadcasting Organizations, Geneva (11 Nov 2004) 3.

25 Part IV being referred to is that of the Australian Copyright Act under which broadcasts are protected. 
It is simply the transmissions themselves". ${ }^{26}$ The signal-centric broadcast copyright protection is in accord with the Satellite Convention. ${ }^{27}$ The Convention protects the signal irrespective of the content or the ownership thereof. This kind of protection seeks to maintain the delicate balance between the interests of broadcasters and those of the content owners. ${ }^{28}$ In order to keep the equilibrium of the said competing interests, the Satellite Convention does not give broadcasting organizations any exclusive rights over their broadcasts. ${ }^{29}$ Any exclusive rights would create another layer of rights on top of those owned by the copyright owners. The new layer will not sit well with Article 1 of the Rome Convention. The Article provides that the protection granted under the Rome Convention shall leave intact and shall in no way affect the protection of copyright in the literary and artistic works. The copyright envisaged in the safeguard clause is that which relates to the underlying content, when applicable.

In 2006, during the ongoing negotiations for the updating of the rights of broadcasters, WIPO produced an informal paper based on the consensus so far generated in which the object of protection of broadcast copyright was agreed as the signal. ${ }^{30}$ However, the nature and specific scope of protection were not agreed upon. WIPO avers that the signal-based approach is preferable because, unlike the content-based approach, it would not lead to overlapping of protection, which would impair access to information. ${ }^{31}$ Supporting the signal-centric protection to the neighbouring rights of broadcasters, the South African delegation at the June 2011, WIPO SCCR meeting argued:

"It is further proposed that the definition of a broadcast should limit the ambit of the protection granted by the draft treaty, limiting this protection to the broadcast signal and not the underlying content rights in the broadcast work."

In its revised consolidated document on the rights of broadcasters, WIPO reaffirmed and emphasized that the object of protection in a broadcast

26 Ricketson and Creswell The Law of Intellectual Property: Copyright, Designs and Confidential Information 2ed (2002) par 8:100.

27 Each Contracting State undertakes to take adequate measures to prevent the distribution on or from its territory of any programme-carrying signal by a distributor for whom the signal emitted to or passing through the satellite is not intended. Article 2 Satellite Convention. It should be noted that the Satellite Convention was designed to fight trans-border theft or piracy of broadcast signals propagated via a satellite. It never gave broadcasters any exclusive rights. In a way, it is viewed as a protective tool, a shield as it were.

28 Article 1 . It is clearly provided that the protection granted under the Rome Convention shall leave intact and shall in no way affect the protection of copyright in literary and artistic works. Consequently, no provision of the Convention may be interpreted as prejudicing such protection.

29 World Broadcasting Union WIPO's Proposed Broadcasters' Treaty presented at the WIPO SCCR meeting on the Rights of Broadcasting Organizations Geneva (May 2010) 7. World Broadcasting Union brings together several continental broadcasting unions like, the European Broadcasting Union, African Union of broadcasting, Caribbean Broadcasting Union, among others.

30 WIPO The WIPO Treaty on the Protection of Broadcasting Organizations: Informal Paper circulated at the SCCR meeting Geneva (3-7 November 2008) 10.

31 Ibid.

32 South Africa Proposal to the Draft Treaty on the Protection of Broadcasting Organizations paper presented at the WIPO SCCR meeting (5-24 June 2011) 24. 
copyright is the signal but not the programme embedded therein. ${ }^{33}$ The European Audiovisual Observatory reiterated this position ${ }^{34}$ in its assessment of the ongoing global efforts to update the neighbouring rights of broadcasters as well as by Hinze and Esguerra who hold that the most preferable model of addressing the broadcasters' related rights is a narrow signal-based approach. ${ }^{35}$ The controversy revolving the two approaches has dogged WIPO in its attempt to update the rights of broadcasting organizations whose preparatory work started in Manila, in $1997 .{ }^{36}$ Because of the centrality of the two approaches, this article gives an overview of their scope and nature hereinbelow.

\section{CONTENT-BASED APPROACH VERSUS SIGNAL- BASED APPROACH}

The categorisation of the protection of neighbouring rights of broadcasters as either signal or content-based is very important. This categorisation would affect the substantive rights conferred upon broadcasting organizations as neighbouring rights holders. A protection that is content or right-based would grant broadcasters substantive rights that go beyond the life of a signal. On the other hand, a signal-based approach would give broadcasters rights that are adequate to fight signal piracy and not exercise any rights over the underlying content.

\section{Content-based approach}

The content-based approach is also referred to as right-based approach. According to Rafiei, content-based approach follows the same rationale, justificatory argument and /or raison d'ètre for the broadcaster's neighbouring rights as provided for in the Rome Convention. ${ }^{37}$ In other words, neighbouring rights of broadcasters (broadcast copyright) subsist side by side with the copyright of the underlying content, except that the justification for existence is based on the broadcaster's technical,

33 WIPO Revised Consolidated Text on Definitions, Object of Protection, and the Rights to be Granted document distributed by WIPO at the SCCR meeting Geneva (9-13 May 2016) 4; see also WIPO Draft Treaty on the Protection of Broadcasting Organizations paper distributed at the SCCR meeting Geneva (16-20 December 2013) 2.

34 European Audiovisual Observatory "Audiovisual Sports Rights between Exclusivity and Right to Information: Updating Intellectual of Intellectual Property Rights of Broadcasting organizations" 2006-2 IRIS Plus 27.

35 Hinze and Esguerra "It's Back: WIPO Broadcasting Treaty Returns from the Grave" (July 2011) http:www.eff.org/deeplinks/2011/07/its-back-wipo-brodcasting-treaty-return-from-thegrave.pdf (accessed on 2017-04-04).

36 See WIPO WIPO Symposium on Broadcasting, New Communication Technologies and Intellectual Property 14.

37 See Rafiei The Possibility of Granting New Legal Protection and IP Rights to Broadcasting Organizations Against the Unauthorized Exploitation of their Broadcasts; see also Helberger Neighbouring Rights Protection of Broadcasting Organization: Current Problems and Possible Lines of Action paper presented to the Council of Europe, Strasbourg (May 1999) 151. The fact that the Rome convention gives exclusive rights to broadcasting organizations implies that they control access to content contained in the broadcast, hence the name content-based. 
organizational and entrepreneurial contribution. ${ }^{38}$ In this context, the broadcasters enjoy rights akin to but they are not copyrighted. The Rome Convention grants broadcasting organizations the right to authorize or prohibit the rebroadcasting of their broadcasts; the fixation of their broadcasts; the reproduction as well as the communication to the public of their telecasts. ${ }^{39}$ The other neighbouring-based international instruments that have also adopted a content-based protection approach are the WIPO Performances and Phonograms Treaty of 1996 (WPPT) and the Beijing Treaty on Audiovisual Performances (BTAP) of 2012. ${ }^{40}$ When a broadcasting organization prohibits a given use of its signal, then, de facto, automatically, that prohibition also extends to the content of the programmes carried by that signal, but only in that particular context and in that particular combination. ${ }^{41}$ To sum up, in a content-based approach, the broadcast signal and the underlying content are two elements that are mutually inclusive and interdependent.

\section{Signal-based approach}

The notion of signal-based protection is underpinned by the desire to restrict protection of broadcast copyright to a signal or programme-carrying signal from the point of uplink to the point of the downlink. ${ }^{22}$ The notion of signalbased protection gained currency during the formative stages of WIPO deliberations on the possible enhancement of the protection of the neighbouring rights of broadcasters under the Rome Convention. ${ }^{43}$ According to Refiei, civil societies and non-governmental organizations mooted the concept of signal-based protection in 1998; which argued that any enhanced protection of broadcasters should be aimed at fighting signal piracy. ${ }^{44}$ In a signal-based protection, substantive and positive exclusive

38 See Tran The Protection of Broadcasters' Rights in a Changing Technological Landscape: A View from South Korea 10 par 2. Because neighbouring rights are based on the investment and entrepreneurial efforts of the broadcaster, they exist irrespective of whether the content is copyrighted or not, is in the public domain.

39 See Article 13. Although the Article does not specifically state that, the rights granted to broadcasters are exclusive; the notion of exclusivity is implied from its wording.

40 Rafiei The Possibility of Granting New Legal Protection and IP Rights to Broadcasting Organizations Against the Unauthorized Exploitation of their Broadcasts 92.

41 Rumphorst "The Broadcasters' Neighbouring Right: Impossible to Understand?" 2006 eCopyright Bulletin 4. The copyright owners of the content of a broadcast are free in this context to authorize any requested use, as long as the user takes it not from the broadcast signal but, instead, direct from the physical medium in which it is embedded and which the broadcaster itself used as a basis of its programme content. The protection of broadcasters is comparable to the protection of phonogram producers in which their entrepreneurial efforts and investments in the form in which they materialize form the basis of protection.

42 See CCIA and KEI "Rights of Broadcasting Organizations" joint paper presented at the WIPO General Assembly, Geneva (October 2012) 10. CCIA and KIE are NGOs then accredited by WIPO to attend SCCR meeting in which their members had interest. CCIA and $\mathrm{KEI}$ are respectively abbreviations for Computer and Communication Industry Association and Knowledge Ecology International.

43 The Rome Convention was the first international instrument to recognize and grant neighbouring rights of broadcasting. Other subsequent instruments that touch on the neighbouring rights are merely adjunctive to the Convention.

44 Rafiei The Possibility of Granting New Legal Protection and IP Rights to Broadcasting Organizations Against the Unauthorized Exploitation of their Broadcasts 92. Among the civil societies and NGOs involved included Electronic Frontier Foundation (EFF); Knowledge 
intellectual property type of rights is not granted. The protection is modelled upon the Satellite Convention. ${ }^{45}$ It is argued that since broadcasters do not create works but transmit them; they should not have any control over the underlying content, information and knowledge but merely exercise control over the signal they generate to transmit their broadcast. ${ }^{46}$ WIPO has adopted the signal-based protection as a basis of the ongoing negotiations on the need to update the neighbouring rights of broadcasting organizations. ${ }^{47}$

To sum up, on the two approaches, it must be pointed out that although the WIPO has approved the signal-approach as the basis of deliberations for the protection, the scope and nature of such protection are in contention. There are those delegates who argue that a signal exists as it is being emitted, but then disappears, being electromagnetic impulses. ${ }^{48}$ Thus, rights in the signal can logically only relate to the simultaneous retransmission of the signal and possibly its fixation. After fixation, it is no longer a signal, but a fixation of the content. ${ }^{49}$ On the other hand, there are those who argue that a signal-based approach would be ineffective and unrealistic. ${ }^{50}$ It would not

Ecology International (KEI), Open Rights Group (ORG); and Digital Media Association (DIMA).

45 The Convention does not grant any intellectual property rights. It only obliges member states to prevent the appropriation of the programme-carrying signals on or from their territories; NGOs, Joint Position of Right Holders on the Revised Consolidated Text for the Protection of Broadcasting Organizations, Joint Paper presented to WIPO Geneva (November 2004). The ensemble of the NGOs comprising AEPO, ARTIS GEIE, BIEM, CISAC, EUROCINEMA, EUROPYA, FIA, FIAPF FIM, CIEM, IFPI, IFTA, IMPALA and UNI$\mathrm{MEl}$; argued that providing a repertoire of additional exclusive rights should be resisted and instead different ways for providing protection for broadcasting organizations should be explored.

46 Sontakke and Bhatt "Scope of Rights of Broadcasting Organizations under Copyright Act, 1957" 2014 RGNUL LR 113. Signal-based protection will merely be used a shield to protect that which the broadcasters generate but cannot be used a sword to claim rights over contents.

47 WIPO Revised Consolidated Text on Definitions, Object of Protection, and the Rights to be Granted 4; see also WIPO Draft Treaty on the Protection of Broadcasting Organizations 2; The emphasis on the signal-based approach is an attempt to narrow the focus of the intended treaty to signal treaty to signal theft and piracy in order to allay the fears and concerns that the new layer of rights over the content of the broadcasts would, in effect, extend protection beyond the expiration of copyright of copyright for each broadcast transmitted and keep or remove content from the public domain. CRS WIPO Treaty on the Protection of Broadcasting Organizations report made to the Congress of the USA Washington (25 January 2008) 4.

48 WIPO The WIPO Treaty on the Protection of Broadcasting Organizations: Informal Paper 10. The view is based on the fact granting rights to broadcasters beyond the fixation will create an overlapping protection that is not necessary for the effective protection of broadcasting organizations and which risks making the access to the broadcast content more difficult; see also WIPO The Rights of Broadcasting Organizations intervention made by the delegation of India at SCCR No. 18 at Geneva (25-29 May 2005) 30.

49 lbid.

50 Among the delegations that prefer broad and post, fixation rights are the European Union. It argues that rights-based approach would adequately protect broadcasters its area of jurisdiction and that its member states already provide a higher level of protection for broadcasting organizations, which is consistent and also goes beyond the provisions of the Rome Convention. EU Submission to the WIPO on the Treaty for the Protection of Broadcasting Organizations document dated 2 July 2006 and submitted WIPO in response to the Non-Paper Document of March 2007 (September 2007) 2. 
address piracy at post-fixation levels especially over non-linear platforms. ${ }^{51}$ Other delegates within WIPO argue against any IP-based protection granted to broadcasters because their activities are technical in nature and outside the purview of copyright. ${ }^{52}$ These divergent views have prolonged the WIPO deliberations on the possible updating of the rights of broadcasters in response to evolving technological changes. Other neighbouring rightholders like phonogram producers and audiovisual performers have had their rights updated respectively under the WPPT of 1996 and BTAP of 2012.

The authors of this article hold the view that any updating of the rights of broadcasters must take account of the current normative global development in the field of other neighbouring rights sectors like audiovisual and phonographic industries. The Beijing Treaty on Audiovisual Performances of 2012 as well as the WPPT and the Rome Convention are anchored upon the content-approach. Reliance upon the Satellite Convention in updating the rights of broadcasters would be anomalous because the Convention does not grant substantive rights to broadcasters. Besides, the nature of protection granted under the Satellite Convention is a point-to-point, which qualifies as the protection of a pre-broadcast signal. It is not every signal, carrying content that is copyright protected; it must be that which is originated by or on behalf of the broadcaster for the reception of the public or part thereof (point to multipoint transmission). The new protection must be couched in a technologically neutral language, which can effectively protect the activities of broadcasters on all platforms. The activity of a broadcaster is not only to generate a signal but also to disseminate that signal embodied with images and/or sounds for reception by the public at large. Thus, a content-based protection resonates well with the current and future development in the broadcasting sector.

\section{BROADCAST COPYRIGHT}

The term broadcast copyright refers to the rights that broadcasters enjoy, in most jurisdictions, over their transmissions to the public of radio and television programmes. These rights form part of neighbouring rights or related rights that were first recognized internationally in 1961 under the Rome Convention. ${ }^{53}$ In this article, the terms neighbouring rights and related

51 Ibid.

52 Among those that are opposed to the grant of new international norms to broadcasting organizations are civil societies. Among the civil societies is the Public Knowledge, which characterizes the proposed treaty a land grand type of instrument that would slow down, or even, stop innovation and creativity. Rossin "Public Knowledge endorses Civil Society Opposition to the WIPO Treaty" May 2014 http://www.publicknowledge/org/news blog/public-knowledge-endorses-civil-society-opposition-to-the-wipo-broadcast-tr. (accessed 2018-01-20).

53 Fiscor Guide to Copyright and Related Rights Treaties Administered by WIPO and Glossary of Copyright and Related Rights Terms (2003) 307. The term related rights or neighbouring rights means the rights of performers in respect of their performances, the rights of phonogram producers in respect of their phonograms, and the rights of broadcasting organizations in respect of their broadcasts. The term related or its French equivalent droits voisins has become the official WIPO expression, for instance, the current permanent WIPO 
rights are used interchangeably. However, in most Anglo-American jurisdictions both authors' rights and neighbouring rights are conflated into copyright while the civil law jurisdictions, which place greater emphasis on the personality of the work's author, give a clear distinction between neighbouring rights and copyright. ${ }^{54}$ The scope of protection of broadcast copyright varies from country to country. Some countries restrict broadcasts to wireless transmission only while others restrict them to both wired and wireless transmissions. Whereas most relevant international instruments do define the activity of broadcasting, they do not, however, specifically define the term broadcasts. ${ }^{55}$ The notion of broadcasts and its meaning, therefore, is implicated in the definition of broadcasting. . $^{5}$

\section{Legal historical background of broadcast copyright}

The history of broadcast copyright can be traced to 1961 when the Rome Convention was adopted. ${ }^{57}$ The Convention was closely followed by the Satellite Convention in 1974, and then the TRIPs Agreement in 1994. This article examines the contribution of each of these international instruments below.

\section{Rome Convention}

The Rome Convention recognized three categories of new right holders, namely, the performers, the phonogram producers, and broadcasting organizations. ${ }^{58}$ Hitherto, and on the global scale, broadcasting organizations did not enjoy neighbouring rights protection. It should, however, be understood that whereas the Berne Convention was negotiated

body in the field of copyright is called the Standing Committee on Copyright and Related Rights (SCCR).

54 See generally UNESCO The $A B C$ of Copyright (2010) 15. Few common law countries like Tanzania have created that distinction between copyright and related rights in its Copyright and Neighbouring Act No 7 of 1999.

55 See eg. Article 3(f) Rome Convention. It defines broadcasting as the transmission by wireless means for public reception of sounds or of images and sounds; Article 2(f) of WPPT also defines broadcasting as the transmission by wireless means for public reception of sounds or of images and sounds or the representations thereof; such transmission by satellite is broadcasting; transmission of encrypted signals is broadcasting where the means for decrypting are provided to the public by the broadcasting organizations or with its consent. The WPPT definition of definition is replicated in Article 2 of the Beijing Treaty on Audiovisual Performances of 2012.

56 WIPO Protection of broadcasting Organizations: Technical Background Paper a document prepared by the WIPO secretariat and presented at the $7^{\text {th }}$ Session of SCCR Geneva (13-17 May 2002). In the paper WIPO points out that in the absence of the object of protection under the Rome Convention, Article 3(f) thereof implies that the object of protection is a signal constituting the wireless transmission of images and/or sounds intended for the reception by the public.

57 Erica Broadcasters as Owners of Neighbouring Rights paper presented at the WIPO Symposium on Broadcasting, Communication Technologies and Intellectual Property Manila (1997) 17.

58 See the preamble to the Rome Convention which states that the "'Contracting States' moved by the desire to protect the rights of performers, producers of phonograms, and broadcasting organizations have agreed as follows ..." 
on the basis of the then existing national copyright laws, the Rome Convention donated rights that parties could incorporate into their municipal laws; the reason for which others call it the "Pioneer Convention". Following the adoption of the Rome Convention, many common law countries (other than the USA) modified their copyright laws to include broadcasts within the categories of protected works and thereby extending to broadcasters' rights analogous to content owners. ${ }^{60}$ The Rome Convention, however, failed to (i) specify the nature of the resource, which the rights are to be exercised; or (ii) delineate the exact manner in which the new rights would interact with the traditional copyright. More importantly, the Convention avoided specifying the parties against whom the rights would operate. $^{61}$

The Rome Convention does not define the term broadcast or programmecarrying signal. $^{62}$ It, however, defines broadcasting as the transmission by wireless means for public reception of sounds or of images and sound ${ }^{63}$ The definition restricts broadcasting to over-the-air transmissions and excludes cable and other wire or interactive transmissions. Under the Convention, the term broadcasting refers only to traditional transmission in which the electromagnetic impulses transporting radio or television programmes are propagated over the air without an artificial guide for public reception. ${ }^{64}$ The wording of Article $3(f)$ of the Rome Convention seems to subsume satellite broadcasting into over-the-air transmissions because artificial devices do not guide the latter other than the geostationary satellite in space itself.

The word transmission implies a distance between the place of origin of the communication and where the images, sounds or broadcasts may originally be seen or heard; or where the recording is situated from which the content of the transmission comes, and the place where the general public may receive it. ${ }^{65}$ In order to satisfy the notion of reception by the public, the

59 Rikeston and Ginsburg International Copyright and Neighbouring Rights 2ed (2006) 46.

60 Balganesh "The Social Cost of Property Rights in Broadcast (and Cable) Signals" 200822 Berkeley Technology LJ 13031312.

61 Balganesh 200822 Berkeley Technology LJ 1303 1312. It should be noted that the lack of clarity and felicity over the subject matter and how it would interact with the copyright in the underlying content is the basis of the ongoing protracted negotiation at the WIPO over the protection of the possible updating of broadcasting organizations.

62 See Article 3 gives a repertoire of definitions of essential broadcasting elements but does not define the concept of broadcast, programme-carrying signal or broadcasting organizations.

63 See Article 3 gives a repertoire of definitions of essential broadcasting elements but does not define the concept of broadcast, programme-carrying signal or broadcasting organizations. Article 3 reflects the state of broadcasting in 1961, which was not only analogues but also executed over Hertzian waves over the air supported by broadcast spectrum. Additionally, it should be noted the definition of broadcasting has since been updated in subsequent neighbouring rights treaties. Among the treaties that have updated the definition is the WPPT in its Article 2(f) which defines the term broadcasting as the transmission by wireless means for public reception of sounds or of images and sounds or of the reception thereof: such transmission by satellite is also broadcasting; transmission of encrypted signal is broadcasting where the means for decrypting are provided to the public by the broadcasting organization or with its consent.

64 WIPO Protection of Broadcasting Organizations: Terms and Concepts paper prepared by WIPO and distributed at the SCCR meeting Geneva (4-8 Nov 2002) par 3.

65 WIPO Protection of Broadcasting Organizations: Terms and Concepts par 8. In covering the distance envisaged in the transmission a broadcasting organization acquires the 
transmission must be point to multipoint and not point-to-point. ${ }^{66}$ In this context, transmissions to one person or a defined group of persons (e.g. in the aircraft, ships at sea) are not broadcasts for the purposes of the Rome Convention. The Convention does not define the notion of "the public". However, the term public was defined as an indeterminate number of potential recipients and therefore implies a fairly large number of persons, in ITV Broadcasting Ltd v TV Catch-Up Ltd. ${ }^{67}$

The failure of the Rome Convention to specifically state what is comprised in the ownership of the broadcast as well as the omission to locate the specific object of protection in the broadcast, sowed seeds of scholastic controversy and divergent interpretations, which is witnessed across the globe. Whether the protection is based on the signal or the content, the scope of protection to be or is granted must maintain a delicate balance between the interests of content owners and those of the broadcasters.

\section{Satellite Convention}

The Satellite Convention, also called the Brussels Convention, was adopted on 21 May $1974 .^{68}$ The Convention is the second international treaty for the protection of broadcasting organizations. The development of satellite communication necessitated the advent of the Satellite Convention. In the wake of this development, the international community realized that there was no worldwide system to prevent distributors from distributing programme-carrying signals transmitted by satellites, which were not intended for those distributors and that this lacuna was likely to hamper the use of satellite communications. ${ }^{69}$ Consequently, the Satellite Convention was constructed to combat mainly trans-border signal theft and piracy particularly of television broadcasts propagated through geostationary satellites. In particular, the Convention was designed to prevent distributors from distributing programme-carrying signals propagated via satellite that is not intended for them. ${ }^{70}$ The Satellite Convention enlarges the scope of protection of broadcasting organizations, by combating the unlawful distribution of the programme-carrying signals transmitted by satellite. ${ }^{71}$

programme content, schedules and transmits an activity involving investment and organizational efforts which justify protection.

66 WIPO Protection of Broadcasting Organizations: Technical Background Paper prepared by the secretariat and presented to SCCR meeting Geneva (4 April 2002) 5.

67 C-607/2011 CJEU. A fairly large number of people is understood a group consisting of a substantial number of people outside the normal circle of the family and its closest social acquaintances.

68 The Convention Relating to the Signal Distribution of the Programme-Carrying Signal Transmitted by Satellite is the official and long name of the Convention. It was adopted at Brussels on 21 May 1974. The Convention protects signals that are distributed from point to point basis.

69 See the preamble of the satellite Convention.

70 Article 2 Satellite Convention. Distribution of the signal is realized once the derived signals are transmitted to the public or any part thereof.

71 WIPO WIPO Intellectual Property Handbook (2001) 322. The protection is extended to programme-carrying signals irrespective of the fact that their emission does not constitute broadcasting according to the definition of the notion under the Rome Convention. This is because the programme-carrying signals protected are those that are point to point. 
The Satellite Convention permits the distribution of the derived signals by unauthorized persons, only if those signals carry excerpts containing current events justified by the informatory purposes or as quotations or short excerpts of the programme carried by the emitted signal, provided that such quotations are compatible with fair practice and are justified by the informatory purpose or in case of developing countries, if the programme carried by the emitted signals is distributed solely for the purposes of teaching, including adult teaching or scientific research. ${ }^{72}$ However, the Convention does not cover distribution of signals that are taken from a direct broadcast satellite (DBS). ${ }^{73}$ A DBS satellite is a high-power satellite that transmits programme-carrying signals directly to the broadcast receiving sets or other devices of consumers or end users. Additionally, the Convention has not protected the transmitted programme since the subject of protection is the signal emitted by the originating organization. ${ }^{74}$

The Satellite Convention does not grant any intellectual property rights or any additional rights specific or exclusive rights to the beneficiaries of the Rome Convention, although it serves the commercial interests of such beneficiaries, and in particular broadcasting organizations. ${ }^{75}$ Although broadcasters do not enjoy any exclusive rights from the Satellite Convention, and most of them dismiss it as a toothless dog, it, however, serves their interests albeit indirectly. ${ }^{76}$

To sum up, the Satellite Convention does not only suffer from technological obsolescence but also does not grant broadcasting organizations exclusive rights over their programme-carrying signals. Besides, being a point-to-point transmission, the Convention falls outside the scope of the notion of broadcasting within the meaning of the Rome Convention. Consequently, its benefits to broadcasters are narrow in scope and thus inadequate.

\section{TRIPs agreement}

The Agreement on the Trade-Related Aspects of Intellectual Property Rights commonly known as the "TRIPs Agreement" was negotiated and concluded as an integral part of the multilateral trade negotiation under the Uruguay Round of the General Agreement on Tariffs and Trade (GATT). ${ }^{77}$ It is a

72 Article 4 of Satellite Convention.

73 Tellez and Waitara A Development Analysis of the Proposed WIPO Treaty on the Protection of Broadcasting and Cablecasting Organizations research paper commissioned by the South Centre on Protection of Broadcasting and Cablecasting Organization Geneva (January 2007) 21.

74 lbid.

75 The Convention Relating to the Signal Distribution of the Programme-Carrying Signal Transmitted by Satellite is the official and long name of the Convention. It was adopted at Brussels on 21 May 1974. The Convention protects signals that are distributed from point to point basis. The Convention only obliges member states to prevent the distribution of programme-carrying signals by any distributor for whom the signals passing through the satellite are not intended.

76 See Fiscor Guide to Copyright and Related Rights Treaties Administered by WIPO and Glossary of Copyright and Related Rights Terms 307. Fiscor considers the Satellite Convention a special agreement envisaged under Article 22 of the Rome Convention.

77 Leesti "Historical Background, General Provisions and Basic Principles of the TRIPs Agreement and Transitional Arrangements" 1998 Journal of Intellectual Property Rights 68 
multilateral trade agreement that is binding on all members of the World Trade Organization (WTO), the successor of GATT. In order to be a member of the WTO, a country must first be party to the TRIPs Agreement. The Agreement established new minimum levels of protection in all fields of intellectual property and defined intellectual property to include copyright and related, trademarks, geographical indications, industrial designs, patents, layout designs (topographies) of integrated circuits, and undisclosed information.

The advent of the TRIPs Agreement was as recognition of the fact that there existed widely differing standards of protection and enforcement of intellectual property rights coupled with the absence of a multilateral framework of principles, rules and disciplines to deal with the snowballing international trade in counterfeit goods ${ }^{5}$ In response to those challenges, the Agreement has two important features hitherto unknown in the previous instruments in the field of copyright and related rights. First, the Agreement provides an elaborate enforcement mechanism to permit effective action against any act infringement of intellectual property rights, including expeditious remedies to prevent infringement. Secondly, the Agreement made its obligations subject to the procedures of the WTO dispute settlement mechanism. ${ }^{80}$

As regards the protection of neighbouring rights, the TRIPs Agreement grants broadcasting organizations a right to prohibit the fixation, the reproduction of the fixation, and the rebroadcasting by wireless means of broadcasts, as well as communication to the public of television broadcasts of the same. ${ }^{81}$ However, the Agreement is open to opting out by member states. ${ }^{82}$ Member states are therefore not obliged to grant neighbouring rights to broadcasting organizations provided that the corresponding rights are extended to authors. ${ }^{83}$ Under the TRIPs Agreement, therefore, the protection of broadcasting is merely optional. ${ }^{84}$ Ogawa bluntly puts it that the opt-out clause threw the rights of broadcasters to the periphery since a

73. The TRIPs Agreement was adopted on 5 April 1994 in Marrakech and came into force on 1 January 1995.

78 See Part II of TRIPs Agreement.

79 Leesti 1998 Journal of Intellectual Property Rights 68 73. The TRIPs Agreement was adopted on 5 April 1994 in Marrakech and came into force on 1 January 1995; see also the preamble of the TRIPs agreement, which summarizes the justification for the Agreement, which includes but not limited to the desire to reduce distortions and impediments to international trade.

80 See WIPO WIPO Intellectual Property Handbook 322. The enforcement mechanisms and the procedures must be employed in such a manner as to avoid the creation of barriers to legitimate trade and to provide the necessary safeguards against their abuse.

81 See Article 14(3).

82 See last paragraph of Article 14(3) which provides that where members do not grant such rights to broadcasting organizations, they provide owners of copyright in the subject matter of broadcasts with the possibility of preventing the above acts (unauthorized fixation of broadcasts, reproduction of fixations, rebroadcasting, as well as communication to the public to telecasts of the same), subject to the provisions of the Berne Convention (1971).

83 Walter "The Relationship and Comparison between the Rome Convention, the WIPO Performances and Phonograms Treaty and the Agreement on the Trade-Related Aspects of Intellectual Property Rights (TRIPs Agreement): The Evolution and Possible Improvement of Protection of Neighbouring Rights Recognized by the Rome Convention" 2000 XXIV

34 Ibid. 
Contracting Party is not obliged to grant rights to broadcasters as long as it complies with the last paragraph of Article 14(3) of the Agreement. ${ }^{85}$ However, if a member state chooses to grant protection for broadcast signals, it must meet the minimum standards under Article 13 of the Rome Convention. ${ }^{86}$ While Bently and Sherman aver that the TRIPs Agreement does not require member states to adhere to the Rome Convention, they concede that it, however, extended substantially the term of protection of performances and phonograms. ${ }^{87}$

To sum up, the TRIPs Agreement did not enhance the protection of broadcasters any more than that granted by the Rome Convention. First, it reduced the exclusive rights under the Rome Convention to a mere right to prohibit while the Rome Convention grants the right to "authorize and prohibit." Under the Rome Convention, this article argues, the exclusive rights could be used as both a shield and sword but under the TRIPs Agreement, they could only be used as a shield to stop piracy. Secondly, the opt-out option given to member states renders the Agreement ineffective and not the broadcasters' first choice.

\section{Elements that may be protected under broadcast copyright}

Broadcasts copyright falls within the ambit and scope of derivative rights. Derivative rights are normally based on one or more pre-existing original works like literary, artistic dramatic and musical works. ${ }^{88}$ Nimmer defines a derivative work as:

"A work based upon one or more pre-existing works, such as a translation, fictionalization, motion picture version, sound recording, art reproduction, abridgement, condensation or any other form in which a work may be recasts or transformed or adopted. A work consisting of editorial revisions, annotations, elaborations, or any other modifications, which, as whole, represent an original work of authorship, is a derivative work."

Derivative rights are also called neighbouring or related rights. ${ }^{90}$ However, not all derivative works may be based on original works. For instance, a sound recording of two quarrelling spouses will qualify for copyright protection but there is no underlying work. ${ }^{91}$ Several original works may

85 Ogawa The Protection of Broadcasters' Rights (2006) 5.

86 See Tran The Protection of Broadcasters' Rights in a Changing Technological Landscape: A View from South Korea 10 par 2.

87 See Bentley and Sherman Intellectual Property Law 4ed (2014) 43. It is imperative to note that while the term of protection for performances and phonograms were extended to 50 years, the term of protection for broadcasts remained at least 20 years from the end of the year in which the broadcast took place.

88 Sihanya Intellectual Property and Innovation Law in Kenya and Africa: Transferring Technology for Sustainable Development (2016) 220.

89 See Nimmer and Nimmer, Nimmer on Copyright par 2:166.

90 Neighbouring rights are rights that neighbour on copyright. Their existence is anchored upon the entrepreneurial efforts as well as investment expended on the original works. The entrepreneurial activity makes the works accessible to the public and generally disseminates them to the public. See WIPO Intellectual Property Handbook (2001) 130.

91 Bainbridge Intellectual Property 5ed (2002) 53. According to Bainbridge, some of the works will fall within the domain of derivative works are, sound recordings, films, broadcasts and 
simultaneously be encapsulated in a derivative work. In a broadcast, for instance, several original works may be incorporated thereto, the ensemble whereof constituting broadcast copyright. According to Rumphorst, derivative rights of broadcasters (which he calls neighbouring rights) are designed to protect the broadcasters' entrepreneurial efforts and investments in forms in which they materialize as an end product from their activity. ${ }^{92}$ He defines the notion of "broadcasts" as electronic signals which carry radio and television programmes and which are transmitted over the air by or on behalf of the broadcasters for reception by the public. ${ }^{93}$ Whether a broadcast copyright should be based on the signal alone or the content embodied into it is the subject of the current WIPO controversy as alluded to in paragraphs 2.1 and 2.2 of this article. However, both original works and derivative works may be incorporated into the signal the ensemble of which is transmitted over the air or via physical conductors for reception by the public.

\section{Original works}

Bainbridge defines original works as authorial works whose creation requires originality. ${ }^{94}$ The Berne Convention's notion of original works is implicated in literary works, artistic works, musical works, cinematographic works, dramatic and choreographic works. ${ }^{95}$ All these works may be incorporated into a transmission in order to complement a broadcast. However, the authors or owners of these works enjoy the exclusive right to authorize broadcasters to incorporate and broadcast or communicate them to the public. ${ }^{96}$ To broadcast a work means to transmit it by wireless means for reception by the public. ${ }^{97}$ The notion of the "public" is not defined either in any international instrument or under any municipal law in Kenya or South Africa. However, in ITV Broadcasting Ltd v TV Catch-Up Ltd, ${ }^{98}$ the Court of

cable programmes. Derivative rights thus largely protect investors and entrepreneurs in such works.

92 Rumphorst 2006 e-Copyright Bulletin 4.

93 Rumphorst 2006 e-Copyright Bulletin 4; see also WIPO Protection of Broadcasting Organization, Terms and Concepts, Working Paper Prepared by the Secretariat WIPO SCCR/8/INF/1 and (Nov 2002) 3.

94 See Bainbridge Intellectual Property 53. Bainbridge enumerates literary works, dramatic works, artistic works, and musical works as original works of authorship, whose creation is authorial in character calling for originality.

95 See Article 2. The expression literary and artistic works is given such a broad interpretation as to cover the works cited.

96 See Berne Convention Article $10^{\text {bis }}(1)$. The Article provides that literary and artistic works shall enjoy the exclusive of (i) the broadcasting of the works or the communication thereof to the public by any means of wireless diffusion of signs, sounds, or images;(ii) any communication to the public by wire or by rebroadcasting of the broadcast of the work, when the communication is made by an organization other than the original one;(iii) the public communication by loudspeaker or any other analogous instrument transmitting by signs, sounds or images, the broadcasts of the work.

97 See Rome Convention Article 3(f); Cf the Kenya Copyright Act s 2(1); Copyright Act of South Africa s 1.

98 Supra; ITV Broadcasting Ltd v TV Catch-Up Ltd C-607/2011 CJEU; (Catch-up TV Ltd was a service that streamed a live television broadcasts of terrestrial and satellite TV channels over internet. The service was accessible over mobile phones and computers. TV Catch-up Ltd required end users to hold a valid licence and use the service within the UK only. ITV and other commercial TV services filed suit against Catch-up TV Ltd contending that the 
Justice of the European Union defined "the public" as an indeterminate number of potential recipients thereby implying a large number of persons. Justice Kitchin observed that the right of communication of a work to the public had to be interpreted broadly to cover all communications to the public not present where the communications originated and included, but not limited to broadcasting and access on demand. ${ }^{99}$ In South Africa, a right of communication to the public is implicated in the right of public performance of a work. ${ }^{100}$ In South Africa, Music Rights Organization (SAMRO) Ltd v Svenmill Fabrics Pty Ltd, ${ }^{101}$ Berman AJ held that the relaying through extension speakers of music in a factory from a programme broadcast by a national broadcasting organization constituted a public performance.

Section 6 of the South African Copyright Act vests in relation to literary or musical works the exclusive rights do the following: (a) reproducing the work in any manner (b) publishing the work if it was hitherto unpublished; (c) performing the work in public; (d) broadcasting the work; (e) causing the work to be transmitted in a diffusion service, unless such a service transmits a lawful broadcast, including the work, and is operated by the original broadcaster;(f) making adaptation of the work and $(\mathrm{g})$ doing in relation to an adaptation of the work any of the acts specified in relation to work in paragraphs $(a)-(e)$ inclusive. Most of the above activities can be subsumed into the act of broadcasting, for instance, performing the work in public as indicated in the SAMRO Ltd $v$ Svenmill Fabrics. ${ }^{102}$ Besides the work having been performed in public, it was also diffused by way of extension speakers and wires in order for the original broadcasts to be accessed in most parts of the factory. In the act of broadcasting, the owner of the copyright also controls a work. ${ }^{103}$ Most of the rights granted under section 6 are replicated in Section 7 and other provisions of the South African copyright law that protect original works.

In Kenya, literary, artistic or musical works and audiovisual works are protected against unauthorized broadcasting and communication to the public. ${ }^{104}$ The High Court in Nairobi restated the position in relation to musical works by holding that performing musical works in a stadium without authority amounts to copyright infringement in Music Copyright Society of Kenya Ltd $v$ Union des radios et Televisions Nationales d'Afrique (URTNA). ${ }^{105}$ Artistic works can be incorporated into broadcasts in form of graphics, designs, sculptures and other forms of audiovisual fixations

streaming amounted to unauthorized communication to the public. The CJEU upheld the argument that the unauthorized internet streaming amounted to communication to the public, holding that an indeterminate number of people accessed it).

99 ITV Broadcasting Ltd v TV Catch-Up Ltd supra par 22.

100 Copyright Act of South Africa s 6.

1983 (1) SA 608 (C).

102 Ibid.

103 See South African Copyright Act No 98 of 1978 s 6 and 7.

104 See Copyright Act s 26(1).

105 HCCC No. 29 of 1996. URTNA and Kenya Broadcasting Corporation had organized a musical extravaganza at the Kasarani Stadium, Nairobi in 1996 bringing together international and local music stars. However, the two organizations did not procure a performance licence from the local collective management organization, MCSK Ltd that applied for and obtained an injunction stopping the extravaganza. 
representing such a work and broadcast to the public. ${ }^{106}$ Audiovisual recordings largely underpin television broadcasting. An audiovisual work is defined as a fixation in any physical medium of images, synchronized either with or without sound, from which a moving picture may by any means be reproduced and includes videotapes and video games but does not include a broadcast.

Literary works may also be incorporated into a broadcast as messages that are scrolled on the television screen simultaneously with broadcasts of the programme. The scrolls may communicate a commercial message or the name of a sponsor of the message. Numerals on the screen indicating the goals in favour of or against participating teams in a match being broadcast may qualify as literary works. However, the ephemeral nature of these elements may render their copyright protection uncertain. ${ }^{108}$

\section{Derivative works}

The derivative works that may be incorporated into a broadcast are performances and sound recordings.

\section{(i) Performances}

The notion of performers is defined under the Beijing Treaty on Audiovisual performers (BTAP) as actors, singers, musicians, dancers and other persons, who act, sing, deliver, declaim, play in, interpret, otherwise perform literary or artistic works or expressions. ${ }^{109}$ The Copyright Act of Kenya defines a performer as an actor, singer, declaimer, musician or other person who performs a literary or musical work and the conductor of the performance of any such work. ${ }^{110}$

The Performer' Protection Act ${ }^{111}$ of South Africa defines a performer in a manner substantially similar to the definition of a performer in the Kenya Copyright Act. As regards to performances in Kenya and South Africa, they must be based on a pre-existing work of authorship. The elements that constitute a performance must be derived from a work. Sporting activities are excluded from the notion of a performance because their execution is

106 See the CJEU ruling in Football Association Premier League (FAPL) v Leisure C-404/2008 and Karen Murphy v Media Services Ltd C-429/2008.

107 Kenya Copyright Act S 2(1). Telecasts comprise either live or recorded broadcasts of audiovisual works. The audiovisual recordings could take the form of dances and other performances, artistic works, documentaries, soaps, talk shows, sports activities and other events.

108 Harms Enforcement of Intellectual Property Rights: A Case Book (2005) 36; see also Copyright Act of Kenya s 22(3); Copyright Act of South Africa s 2(2).

109 BTAP 2012 Article 2(a). The BTAP is the latest multilateral treaty on the protection of audiovisual performances and borrow heavily from the WIPO Performances and Phonograms Treaty of 1996.

110 See s 30(6). The Rome Convention defines performers in Article 3(a) as actors, singers, musicians, dancers and other persons who act, sing, deliver, declaim, play in, or otherwise perform literary or artistic works.

111 The Performers Protection Act No 11 of 1967 s 1(1); see also the Copyright Act of South Africa s 1(1) which defines a performance to include "any mode of visual acoustic presentation of a work ..." 
not based on any pre-existing works. Besides, the primary objective of any sporting activity is the ultimate result and not the display of creativity. ${ }^{112}$ Although sports events may not be protected as performances in Kenya and South Africa, other countries do protect aesthetic or choreographed sports like yoga and ice dancing. ${ }^{113}$

\section{(ii) Sound recordings}

Section 2(1) of the Kenya Copyright Act defines a sound recording as an exclusively aural fixation of sounds of a performance or other sounds or of a representation of sounds regardless of the methods by which the sounds are fixed or the medium in which the sounds are embodied but does not include a fixation of sounds and images. On the other hand, the South African Copyright Act defines a sound recording as a fixation or storage of sounds, or data or signals representing sounds capable of being reproduced, but does not include a soundtrack of a cinematograph film. ${ }^{114}$ According to Sihanya, a sound recording can be any recording of sound including a speech, music, football commentaries embodied in compact disks (CDs), tapes, flash disks or any other tangible medium. ${ }^{115}$ The sound recording may or may not be that of a performance. ${ }^{116}$ What is protected in this context is the media in which the sound is embodied and not the sound itself. Producers of phonograms enjoy the exclusive right to control their communication to the public or their broadcasting in whole or in part. ${ }^{117}$

\section{Kenyan perspectives on broadcast copyright}

\section{З3 1 Overview}

Copyright and related rights protection in Kenya is anchored in the Constitution. ${ }^{118}$ The Constitution provides that the state support, promote and encourage the intellectual property rights of the people of Kenya. ${ }^{119}$ Copyright and related rights may be inferred from the notion of intellectual property rights and the former's constitutional inspiration is constructed accordingly. Copyright protection in Kenya is a function of the Copyright Act. ${ }^{120}$ In Kenya, broadcasters enjoy neighbouring rights protection under

112 Kowalski The Rights to TV Broadcast of Sports Events 34.

113 See eg, Copyright, Designs and Patents Act (CDPA) of UK s 3(1). See also Article 9 of the Rome Convention, which gives member states, a latitude or option by their laws or regulations, to extend the scope of protection of performances to artists who do not perform any work.

114 See s 1(1).

115 Sihanya Intellectual Property and Innovation Law in Kenya and Africa: Transferring Technology for Sustainable Development 220.

116 See s 1(1); see also the definition of sound-recording under s 2(1) of the Kenya Copyright Act.

117 See Copyright Act of Kenya s 28(1)(d); Cf Copyright Act of South Africa s 9(c).

118 The Constitution of Kenya, 2010.

119 Article 40(5). Since the term intellectual property is composite, copyright and related rights are implied in the term, put it differently, copyright and related rights are assimilated into intellectual property.

120 Copyright Act No. 12 of 2001. The edition that the article refers to is that of 2016. 
Section 29 of the Copyright Act. ${ }^{121}$ The Act does not give a specific notion of neighbouring or related rights. Such rights are inferred from the nature and scope of the rights given as well as the beneficiaries thereof. In Kenya, some of the programme content broadcast by broadcasters includes; documentaries, drama shows, cartoons, soap operas, music, news, talk shows and sporting activities. ${ }^{122}$ The programmes are either generated and produced by the broadcasting organizations themselves or acquired from third parties on a contractual basis. ${ }^{123}$

\section{Broadcast copyright in Kenya}

The Copyright Act does not define the word "broadcast" as a noun, which is the subject of protection. ${ }^{124}$ The Act only defines the word broadcast as a verb as the transmission by wire or wireless means, of sounds or images or both or the representation thereof, in such a manner as to cause such images or sounds to be received by the public and includes transmission by satellite. ${ }^{125}$ What is defined therefore is the activity of broadcasting and not a broadcast. From the foregoing definition, the scope of broadcasting covered is broader than in the Rome Convention because the former extends protection to both over the air as well as wire transmissions. Wireless transmission presupposes the use of electromagnetic waves of frequencies in space without an artificial guide for direct reception by the general public. ${ }^{126}$ On the other hand, transmission by wire implies the propagation of the electromagnetic waves via physical conductors for direct reception by the public. ${ }^{127}$ The Copyright Act does not, however, define the notion of the general public. In the absence thereof, one relies on other jurisdictions where the concept has been interpreted. In the European Union, the notion of "public" was constructed by the Court of Justice of the European Union (CJEU) as an indeterminate number of potential recipients outside the normal family circle and its closest social acquaintances. ${ }^{128}$

121 The section is titled the nature of copyright in broadcasts.

122 Were The Impact of Locally-Generated TV Programmes on the Kenyan Television Viewers in Dagoretti Sub-Location, Nairobi: Case Study of Citizen Television (unpublished MA Thesis, University of Nairobi 2015) 3.

123 Were The Impact of Locally-Generated TV Programmes on the Kenyan Television Viewers in Dagoretti Sub-Location, Nairobi: Case Study of Citizen Television 3. The programmes that are produced by the broadcaster, like news and documentaries copyright vest in the broadcasters itself and those acquired on licence from third parties the copyright vests and remain vested in the owner, the transmission notwithstanding.

124 The term broadcasts is used in various Sections of the Act but it is not defined.

125 See s 2(1). This definition though broader than in the Rome Convention, it is however, narrow than in the latest neighbouring rights treaty, the 2012 Beijing Treaty on Audiovisual Performances which defines broadcasting as the transmission by wireless means for public reception of sounds or of images or of images and sounds or of the representations thereof; such transmission by satellite is also broadcasting; transmission of encrypted signal is broadcasting where the means of decrypting are provided to the public by the broadcasting organization or with its consent.

126 WIPO Protection of Broadcasting Organizations: Terms and Concepts par 23.

127 European Audiovisual Observatory "Legal Protection of Broadcast Signals" 2004 Iris Plus Legal Observation of the European Audiovisual Observatory Journal 4.

128 ITV Broadcasting Ltd v TV Catch-Up Ltd C-607/2011 CJEU. 
The Copyright Act of Kenya further provides a repertoire of limitative works that are protected under copyright. ${ }^{129}$ The Act does not, however, define the term broadcasts; nor does it specify the nature of resource over which the exclusive rights that attach to broadcasts are to be exercised and against whom. The apparent clarification under the Act that a "broadcast shall not be eligible for copyright till it has been broadcast"130 creates even greater ambiguity. A transmission qualifies to be called a "broadcast" because it is either interactive or non-interactive point to multipoint transmission intended for reception by the general public. A transmission, which is not so intended, is not a broadcast but a pre-broadcast signal, which is not a subject of copyright or neighbouring right. ${ }^{131}$ The concept of broadcasts is thus implicated in the definition of the term broadcast as a verb to mean the dissemination of streams of signals embodied with images and/or sounds for the reception of the public or part thereof. ${ }^{132}$ The images or sounds may or may not be based on any existing works. Therefore, a broadcast may encompass the ensemble of the programme, technical and organizational output of a broadcasting organization.

The Kenyan copyright law does not require that broadcasts be original or be reduced into a material form in order to qualify for protection. ${ }^{133}$ It would, therefore, appear that since broadcasts are not works that the law requires that they be original, and reduced into a tangible form they are, ipso facto, excluded from that requirement. In other words, a broadcast need not be original and recorded before it attracts copyright protection. This is in consonance with the popular view that there is no requirement that broadcasts be original because many, like broadcasts, can fail the threshold because a broadcast cannot be original in the popular sense. ${ }^{134}$ The only requirement the transmission must fulfil is that it must either be over the air or by wire and intended for reception by the public and the broadcaster takes editorial, legal and financial responsibility for its dissemination.

${ }^{129}$ S 22(1). The works include literary works; artistic works; musical works, audiovisual works, sound recordings; and broadcasts.

130 See s 22(2). A broadcast only qualifies to be called as when it is intended for the reception of the public. Any transmission not intended for reception by the public is not a broadcast within the meaning of the Act. The clarification may have been lifted from s $2 A$ of the Copyright Act of South Africa, which is designed and structured so differently as to allow for such apparent possibility.

131 WIPO Protection of Broadcasting Organizations: Terms and Concepts par 23. Prebroadcast signals are those not intended for direct reception by the public but are meant for private use either by the distributaries of the originating broadcasters or by other local or foreign broadcasting organizations. Thus, the clarification does not achieve the intended purpose, as it is superfluous.

132 WIPO Protection of Broadcasting Organizations: Terms and Concepts par 4.

133 See s 22(3) of Copyright Act. The provision states that a literary, musical or artistic work shall not be eligible for copyright unless: (a) sufficient effort has been expended on making the work to give it original character; and (b) the work has been written down, recorded or otherwise reduced to a material form.

134 See Bainbridge Intellectual Property 53; see also Sihanya Intellectual Property and Innovation Law in Kenya and Africa: Transferring Technology for Sustainable Development 220. 


\section{З 33 Does Kenya embrace signal or right-based approach protection?}

The Copyright Act does specify the object of protection in a broadcast copyright. Paragraphs 2.1 and 2.2 have analysed the two competing approaches in relation to the protection of broadcasting organizations in their broadcasts. This sub-paragraph finds that the broadcast copyright protection in Kenya is right or content-based. In support, thereof the article examines the nature and scope of rights broadcasters enjoy in Kenya as well as the emerging jurisprudence of the courts.

\section{(i) Nature and scope rights}

The Copyright Act of Kenya does not mention the concept of the signal. ${ }^{135}$ The definition of a broadcast in Kenya implicates a dissemination of electromagnetic energy carrying images or sound for reception by the public. The notion of the signal is implicated in the definition of broadcasting or the verb broadcast. According to Rumphorst, broadcasts are the electronic signals that carry radio or television programmes, and which are transmitted over the air by or on behalf of the broadcaster for reception by the public. ${ }^{136}$ A broadcast signal must reflect the broadcaster's organizational, technical and entrepreneurial output. In the ongoing WIPO negotiations over the updated broadcasters' related rights, the scope of economic rights that broadcasters should enjoy is not agreed in a signal-based approach. Whereas it is argued that the nature of rights should mirror the Satellite Convention, there are those who argue that such rights if granted should not go beyond the fixation of a live broadcast. ${ }^{137}$ They argue that the protection to be granted should be based on the model in the Satellite Convention. The Rome Convention itself is rights- or content-based because it grants exclusive rights to broadcasters on top of those that content owners enjoy. It thus contested that within the WIPO membership that a signal is not a concept known in the intellectual property landscape and any intellectual property rights-based on the signal would be ineffective.

The Copyright Act extends protection to broadcasting organizations by granting them exclusive rights the control the doing in Kenya any of the

135 See s 2(1).

136 WIPO Protection of Broadcasting Organizations: Technical Background Paper; Rumphorst "Protection of Broadcasting Organization" 199327 Copyright Bulletin 13. The broadcast signal should be seen in the context of the total programme output from which the broadcaster is editorially and legally responsible. This means that a signal distributor who is commissioned by the broadcaster to distribute the programme content does not become a broadcaster by the mere fact of such distribution.

137 See NGOs report. The Convention does not grant any intellectual property rights. It only obliges member states to prevent the appropriation of the programme-carrying signals on or from their territories; NGOs, Joint Position of Right Holders on the Revised Consolidated Text for the Protection of Broadcasting Organizations, Joint Paper presented to WIPO Geneva (November 2004). The ensemble of the NGOs comprising AEPO, ARTIS GEIE, BIEM, CISAC, EUROCINEMA, EUROPYA, FIA, FIAPF FIM, CIEM, IFPI, IFTA, IMPALA and UNI-MEI; argued that providing a repertoire of additional exclusive rights should be resisted and instead different ways for providing protection for broadcasting organizations should be explored. 
following acts, namely, (i) the fixation and the rebroadcasting of the whole or substantial part of the broadcast, (ii) the communication to the public of the whole or a substantial part of a television broadcast and, (iii) the copyright in a telecast shall include the right to control the taking of still photographs therefrom. ${ }^{138}$ It would appear that the exclusive rights broadcasting organizations enjoy in Kenya are post-fixation rights. Post-fixation rights do deal with the content as opposed to the signal. For instance, if a rebroadcasting is based on a fixation of a broadcast, it means the original signal disappears, leaving behind the content and the rebroadcasting is carried by a new signal over which the original broadcaster could not possibly have any right. Additionally, the taking of still photographs could be content and not signal, as it is imperceptible. One cannot take a still photograph of a signal but of a programme embodied in the signal.

\section{(ii) Jurisprudence over broadcast copyright in Kenya}

In the face of want of clarity and felicity over the broadcast copyright, the jurisprudence evolving from the Kenyan courts tends to suggest that broadcast copyright revolves around the programme content transmitted by the signals and thus rights-based. The Supreme Court of Kenya held that the retransmission of free over the air broadcasts over pay TV services and signal distribution networks was not a rebroadcasting of the respondents' content because the appellants were not broadcasting organizations since they did not take financial and editorial responsibility for the selection and arrangement of content in Communications Commission of Kenya v Royal Media Services $L t d{ }^{139}$ While reversing the Court of Appeal decision, the Supreme Court emphasized that:

"The appellants did not interfere with the broadcast content of the 1st, 2nd, and $3 d$ respondents. The content was delivered digitally to without interference from the signal distributor. As they were not rebroadcasting the content, we find that the appellants did not infringe the intellectual property rights of the 1st, 2nd, and 3d respondents."

The Supreme Court judgment while espousing a content or rights-based approach to broadcast copyright seemed to have muddled and erroneously constructed jurisprudence that for an infringing rebroadcasting to take place, the infringing broadcaster must be one that takes financial and editorial responsibility for the selection and arrangement of the content. An infringing broadcaster cannot possess the two attributes, the reason for which its acts are characterized as infringement. The decision is tantamount to rewarding piracy and unjust enrichment.

In another development, the High Court in Nairobi granted an injunction against the defendants for rebroadcasting the 2014 FIFA World Cup tournaments that took place in Brazil over which the plaintiff held exclusive

138 See s 29. Pegging the rights granted on the signal will cause practical difficulties. For instance, how would one determine the quantum of signal rebroadcast in order to decide when a substantial part thereof has been retransmitted?

1392014 eKLR par 243. The case was an appeal from the Court of Appeal in which the Appellants were restrained from rebroadcasting on the pay TV channels and two licensed signal distributor outlets the broadcasts of the respondents' authority.

140 Communications Commission of Kenya $v$ Royal Media Services Ltd supra par 243. 
broadcast rights, in Kenya Broadcasting Corporation $v$ Wananchi Group. ${ }^{141}$ The Court intimated that in so doing, the defendants violated the plaintiff's copyright in the matches. In delivering the judgment, the High Court appreciated the fact that what was being rebroadcast was not the signal but the underlying content of the plaintiff. ${ }^{P 2}$ Although the underlying content comprised football matches which themselves are not copyrightable, the Court may have taken into consideration the fact that the broadcasters' neighbouring rights are based on their entrepreneurial efforts and not on any creativity. ${ }^{143}$ In any case, a broadcast need not be original for it to attract copyright in Kenya.

In Kenya therefore, the obtaining jurisprudence and the statutory underpinning support content that is a tangible basis of determining broadcast copyright. The Copyright Act extends to broadcasters exclusive rights who exercise can only viably extend to content. For example, a right of reproduction or rebroadcasting can only depend upon content and not a signal, which is transient and intangible. The approach, as Colantuoni and Navazio argue, is designed to achieve a commercial function in order to stimulate sustainable strategic investment in the sports industry, for instance, which falls outside authorial copyright protection.

\section{South African perspective on broadcast copyright}

\section{Overview}

The advent of the protection of broadcasts in South Africa can be traced to the 1965 Copyright Act of South Africa. ${ }^{144}$ According to Copeling, the nature of rights granted to broadcasters under the 1965 Act mirrored the 1956 UK, Copyright Act and such rights were depending upon copyright in the content embodied to the signal. ${ }^{145}$ It would appear therefore that Britain had greater influence in the formulation of the protection of broadcast copyright in South Africa than the Rome Convention. ${ }^{146}$ The current 1978 Copyright Act replaced the 1965 Copyright Act.

141 See HCCC No 254 of 2014; see also Kenya Broadcasting Corporation v Royal Media Services Ltd HCCC No 36 of 2010. In this case the plaintiff filed a copyright infringement suit and obtained the injunction against the defendant for making off-tube commentaries of live television broadcast of the 2010 Africa Cup of Nations tournaments that took place in Angola holding that such unauthorized simultaneous radio commentaries based on live telecasts infringed the plaintiff's copyright.

142 It is imperative to not that the content itself having been football matches were not copyrightable.

143 See Rumphorst 2006 e-Copyright Bulletin 4.

144 See s 15(1) of the Copyright Act No 63 of 1965.

145 Copeling "Copyright in Broadcasts in the Republic of South Africa" 1972 Comparative and International Law Journal of Southern Africa 4. The 1965 Act extended copyright to the SABC radio and television broadcasts only. Such protection was dependent on copyrightability of the underlying content. If the underlying content was not copyrightable and so were the broadcasts.

146 It should be noted that to date South Africa is not signatory to the Rome Convention. 


\section{Broadcast copyright in South Africa}

Just like their counterparts in Kenya, broadcasters in South Africa enjoy neighbouring rights protection. However, the Copyright Act of South Africa does not specifically mention neighbouring or related rights. ${ }^{147}$ However, these rights are implicated in the beneficiaries and exclusive rights that are provided. In South Africa, both the author's rights and neighbouring rights are assimilated into copyright in consonance with the tradition that is common in most Anglo-American jurisdictions. ${ }^{148}$ Neighbouring rights of broadcasters are protected in Sections 10 and 11 of the South African Copyright Act.

Section 10 grants broadcasters exclusive right to authorize the indirect or direct reproduction of the broadcast in any manner or form, including taking still photographs of a telecast; rebroadcasting the broadcasts; or causing the broadcasts to be transmitted in diffusion services unless the original broadcasters operate such services. ${ }^{149}$ Although conceptually the copyright protection of broadcast organizations is based on the signal, the commercial imperatives dictate that the protection extends to the content. A broadcast is not a tangible object but a dissemination of electromagnetic energy transporting images or sounds or both for reception by the public. ${ }^{150}$ Copyright cannot subsist in a signal per se but in perceptible substance in the form of images and sounds encoded as a signal by a broadcaster; transmitted and finally decoded as received by the public. ${ }^{151}$ It is against this backdrop that the exclusive rights granted under Section 10 extend to the content embodied into a signal. For instance, the exclusive right over the taking of still photographs of a telecast cannot subsist in a signal. It must be exercised on the content itself that constitutes moving images. The same analogy extends to the right of rebroadcasting of a broadcast.

Section 11 grants copyright in programme-carrying signals by which the owner is vested with exclusive right to undertake or authorize the direct or indirect distribution of such signals by any distributor to the general public or part thereof in or from South Africa. The Act defines distribution in relation to the derived signal as an operation by which a distributor transmits a derived signal to the general public or part thereof. ${ }^{152}$ The provision does not grant any specific economic rights otherwise than empowering broadcasters to control any unauthorized distribution of the derived signal in and from South Africa. It does grant broadcasters any of the rights granted under Section 10 like the right of fixation, reproduction, or taking of still photographs of a

47 South African Copyright Act No 98 of 1978.

148 UNESCO, ABC of Copyright (1981) 15. The Anglo-American tradition of copyright places greater emphasis on the economic justification of intellectual property while the civil law jurisdiction places more emphasis on the personality of the author. Thus the distinction between copyright and neighbouring rights is more conspicuous in the latter than the former; the reason for which in South Africa and Kenya both authorial and entrepreneurial works are conflated in copyright.

149 Although the right of fixation is not specifically granted in the Act, it is however implied from the right of reproduction. A reproduction of a broadcast must be based on a fixation. A broadcast must first be fixed before it is reproduced.

150 Handler 200325 Sydney LR 407.

151 Laddie et al The Modern Law of Copyright and Designs par 8:15.

152 See $s$ 1(1). 
telecast. The protection is to a large extent modelled upon the Satellite Convention, which protects programme-carrying signals and not the content that those signals may carry. ${ }^{153} \mathrm{It}$, therefore, follows that the signal will be protected even if its content is unprotected by copyright or is in the public domain

The Copyright Act of South Africa characterizes broadcasts and programme-carrying signals as works and fall within the repertoire of works protected under copyright. ${ }^{154}$ In South Africa, all works envisaged under Section 2(1) must be original and be written down, recorded, represented in digital data or signals or otherwise reduced to a material form. ${ }^{155}$ However, the Act exempts broadcasts and programme-carrying signals from the requirement of materiality or tangibility. ${ }^{75}$ This means that a broadcast or programme-carrying signal need not be fixed in a material form before it enjoys copyright but it must be original in the manner the term is understood in copyright.

The Copyright law also qualifies the stage at which a broadcast or a programme-carrying signal should attract copyright, and states that it is at the stage at which a satellite has transmitted a broadcast or a programmecarrying signal. ${ }^{157}$ The copyright qualification clause under Section $2 \mathrm{~A}$ seems to suggest that there could be a broadcast, which is not copyrightable and that the programme-carrying signal is only protected at the downlink stage whether it is meant for public reception or not. This article holds that the" broadcast" which has not been broadcast is confusing. Qualifying a signal emitted to the satellite as a broadcast is confusing because the satellite transponders in space cannot qualify as the public in terms of the definition of a broadcast. That signal cannot qualify to a broadcast but a prebroadcast signal. Additionally, the programme-carrying signals are only protected once emitted through the satellite irrespective of whether they are meant for public reception or not.

The Copyright Act of South Africa defines a "broadcast" when used as a noun as a telecommunication service of transmission consisting of sounds, images, signs, or signals which: - (a) takes place by means of electronic waves of frequencies of lower than $3000 \mathrm{GHz}$ transmitted in space without artificial conductor, and (b) is intended for reception by the public or sections of them, and includes the emitting of programme-carrying signals to a

153 The Convention Relating to the Signal Distribution of the Programme-Carrying Signal Transmitted by Satellite is the official and long name of the Convention. It was adopted at Brussels on 21 May 1974. The Convention protects signals that are distributed from point to point basis.

$154 \mathrm{~S} 2(1)$. It provides that subject to the provision of this Act, the following works, if they are original, shall be eligible for copyright: literary works; musical works; artistic works; cinematograph film; sound recordings; broadcasts; programme-carrying signals; published editions; and computer programs.

155 S 2(1); s 2(1)2 of South Africa Copyright Act.

156 See s 2(2). The exemption of broadcasts and programme-carrying signals was perhaps intended to extend protection to live transmissions of events and content, which may not fulfill the tangibility criterion.

157 See s 2A. The Section provides that a "broadcast or programme-carrying signal shall not be eligible for copyright, until, in case of a broadcast, it has been broadcast and, in case of a programme-carrying signal, it has been transmitted by a satellite". 
satellite, and, when used as a verb shall be construed accordingly. ${ }^{158} \mathrm{~A}$ programme-carrying signal means a signal embodying a programme that is emitted through a satellite. ${ }^{159}$

The definition of a broadcast covers free over the air transmission only and excludes transmission by wire like cable and internet transmissions from the ambit of broadcasts. A signal embodied with programmes, which are emitted to a communication satellite in space is also assimilated to a "broadcast." However, it is a "broadcast" that is not intended for public reception and thus not protected. On the part of programme-carrying signals, they are only protected after having been emitted through a satellite whether they are meant for the reception by the public or not. This protection is modelled on the provisions of the Satellite Convention in which the prohibited acts are the unauthorized distribution of programme-carrying signals. ${ }^{160}$ The concept of distribution is broad enough to cover both free over the air and cable or fixed communications. ${ }^{161}$ Just like the Satellite Convention, the owners of programme-carrying signals do not enjoy exclusive rights under the copyright law of South Africa.

\section{Does South Africa embrace the signal- or content- based approach?}

In examining the issues, one needs to look at the rights granted under Sections 10 and 11 while having regard to the copyright requirements under Section 2(1) of the South African Copyright Act. Section 10 grants broadcasters exclusive rights the exercise of which revolves around the content and not the signal. This is because a signal is imperceptible and transient and besides has no economic value on its own. In that context, the protection of broadcasters under Section 10 is rights- or content-based. On the other hand, Section 11 is focused on protecting the programme-carrying signal alone against piracy. The protection extends to the signals regardless of whether the content is copyright-protected or not. The protection is modelled upon the Satellite Convention, which protects programme-carrying signals without bestowing in broadcasters any intellectual property rights. Like the Satellite Convention, Section 11 does not bestow on broadcasters and specific economic rights. Consequently, Section 11 grants copyright protection, which is signal-centric.

160 Each Contracting State undertakes to take adequate measures to prevent the distribution on or from its territory of any programme-carrying signal by a distributor for whom the signal emitted to or passing through the satellite is not intended. Article 2 Satellite Convention.

161 See Tellez and Waitara A Development Analysis of the Proposed WIPO Treaty on the Protection of Broadcasting and Cablecasting Organizations 21.

162 See $\mathrm{s} 11$. Copyright in the programme-carrying signals vests the exclusive right to undertake or authorize the indirect or direct distribution of the signal by the distributor.
} 


\section{(i) Copyright requirement and a broadcast}

One of the requirements for subsistence of copyright in South Africa is that a work must be original. ${ }^{163}$ Sections 3 and 4 of the Copyright Act 63 of 165 also provide that copyright can only subsist in original works of authorship. For a broadcast to be copyright protected, it must be original. The Acts do not define the notion of originality. Courts and intellectual property scholars in South Africa have, therefore, constructed the notion of originality.

\section{(ii) Originality in broadcasts}

Originality does not mean that the work be in any way unique or inventive but merely that it should be a product of the author's own labours and endeavours and should not be copied from other sources. ${ }^{164}$ Originality is a matter of degree depending on the amount of skill, judgment and labour involved in the making of the work. ${ }^{165}$ There is no precise formula that can be prescribed to determine the quantum of skill, labour and judgment necessary to attain originality. On his part, Smith states that establishing that the author used sufficient skill and labour in making the work is necessary in order to justify copyright protection and that each case is normally considered on its own merit. ${ }^{166}$ However, reliance can be placed upon the ruling in the Kenyan High Court at Nairobi in which it was held that the test to be applied in determining the quantum of substantiality in skill, labour and judgment expended on a work is a qualitative and quantitative one. ${ }^{167}$ Additionally, in the English case of Exxon Corporation $v$ Exxon Insurance Consultation $L t d,{ }^{168}$ the Court declined to recognize alleged copyright in the single word "Exxon" for want of substantiality of labour and skill. The concept of originality was amplified in Pan African Engineers Pty Ltd $v$ Hydro Tube Pty Ltd. $^{169}$ In the suit, Boshoff $\mathrm{J}$ illuminated on originality holding that originality does not mean that the work be an expression of original or inventive thoughts because Copyright Acts are not concerned with originality of ideas but with the expression of thoughts. The work must, therefore, be original in the sense that it was not copied from another but originated from the author. ${ }^{170}$ Applying the doctrine of originality the South African Supreme Court of Appeal held that designing, formatting and composing field diaries, complete with appointment pages, names of the month, numbers of the weeks and days did not constitute copyright for want of originality. ${ }^{171}$ From the foregoing, it can be argued that the doctrine of originality is constructed

\footnotetext{
163 Harms Enforcement of Intellectual Property Rights: A Case Book 36; see also Copyright Act of Kenya s 22(3); Copyright Act of South Africa s 2(2).

164 See Dean Handbook of South African Copyright Law (1997) 1-15. The principle enunciated in this case was replicated in Haupt t/a Soft Copy $v$ Brewer Marketing Intelligence Pty Ltd 2005 (1) SA 398 (C) 413.

165 Ibid.

166 Smith Copyright Companion: Paper Back (1995) 9-10.

167 Parity Informations Systems Ltd $v$ Vista Solution Ltd (2012) eKLR par 19.

168 (1981) All ER 241.

16919721 SA 471 (WLD).

170 lbid.

171 See Waylite Diaries CC v First National Bank Ltd (1995) 1 SA 645 (AD).
} 
in a context of authorial works, which are tangible and perceptible substances. Electromagnetic impulses are neither tangible nor perceptible.

The most vexing issue is how to measure the originality in a broadcast or programme-carrying signals. Since a broadcast and programme-carrying signals are electromagnetic impulses carrying programmes, such impulses are transient and ephemeral. Besides, such electromagnetic impulses are imperceptible. Originality, therefore, cannot be determined on the basis of a transient and intangible phenomenon. It must, therefore, be anchored on the tangible substance in the form of underlying programmes. ${ }^{172}$ Having regard to the scope of exclusive rights that broadcasters enjoy in South Africa, which is post-fixation in nature, one can argue that the protection of broadcasts in South Africa is content-based. ${ }^{173}$

On the other hand, a programme-carrying signal does not grant broadcasters any exclusive rights like the right fixation or communication to the public. Exclusive rights implicate the use of content as a means of copyright protection; otherwise, one cannot possibly fix an empty signal or communicate it to the public. The rights inherent in the programme-carrying signal give the broadcasters a right to fight signal theft and piracy. The protection of the programme-carrying signal does not extend to the underlying content. The object of protection, in this case, is the signal to the exclusion of the underlying content. It can be concluded that the protection of the programme-carrying signals is signal-based. Thus, South Africa embraces a dualist approach to broadcast copyright depending on whether the subject work is a broadcast or a programme-carrying signal.

\section{CONCLUSIONS AND RECOMMENDATIONS}

This study sought to examine two competing global approaches to broadcast copyright, namely, signal-based approach and a rights-based approach. Upon deconstruction of the two approaches, the analysis then narrows down to investigate the extent to which the two approaches play out in Kenya and South Africa. The analysis finds out that in Kenya, the popular approach is the rights-based approach. The drawing of this conclusion is grounded upon the scope of exclusive rights that broadcasters enjoy in Kenya, which goes beyond the life of the signals transporting the programmes. Additionally, the Court decisions that have been handed down in Kenya in relation to broadcasts do support a content-based approach.

In South Africa, the investigation has found out that the protection of broadcasts takes a two-tier dimension. First, the protection of broadcasts is right-based while the protection of programme-carrying signals is signalcentric. The former gives protection to broadcasting organizations, which extends to the signal itself. Besides, it gives exclusive rights to broadcasters

172 See Handler 200325 Sydney LR 407. The philosophy underlying support for rights or content approach is that a signal does not have any commercial separate from the programme it carries.

173 See s 10 of the South African Copyright Act. The exclusive rights that broadcasters enjoy over their broadcasts include; the reproduction right; the rebroadcasting rights; the right over the taking of still photographs of telecasts; a right of transmission over diffusion services. The right of fixation is implied in the right of reproduction because a reproduction is always based on a fixation. 
whose exercise is dependent upon the underlying content. On the other hand, the latter approach (signal-centric) gives the broadcasters a right to undertake or authorize the direct or indirect distribution of such signals by any distributor to the general public or part thereof in or from South Africa. It does not give exclusive rights to broadcasters but gives them the power to fight signal piracy.

Overall, in the two jurisdictions, the rights of broadcasters should be updated taking into account the evolution of new technologies, including the digitization of not only the programme transmission but also the production and distribution thereof.

The protection of the neighbouring rights of broadcasting organizations should be entrepreneurial in its characterization and not authorial. Such protection is anchored upon the broadcaster's entrepreneurial, organizational, and technical contribution and is not on its authorial contribution. In this context, originality is irrelevant in this contribution as locating it in a broadcast is difficult. A signal is too transient and imperceptible to form a basis of localization of originality. Conversely, the content the broadcasters transmit belongs to the authors, and if they constitute works, their originality exists before transmission.

In South Africa, the differentiation between a broadcast signal at the uplink and downlink levels complicates the conceptualization of signal piracy. In a digital environment, piracy or signal theft can take place in equal measure at the two stages, whether the signal is emitted to or through the satellite. Besides, the activity of broadcasting should be technology-neutral. Internationally satellite broadcasting is conflated into broadcasting. Article $2(f)$ of the WPPT subsumes programme-carrying signals into broadcasting. Thus, the differentiation between a broadcast and a programme-carrying signal based on the means of signal delivery is superfluous. 